\title{
ANALISIS KARAKTERISTIK PERILAKU MENGEMUDI PADA GENERASI Z DI SEKOLAH TINGGI TRANSPORTASI DARAT
}

\author{
Firga Ariani,M.MTr \\ Dosen STTD \\ J1. Raya Setu no.89 \\ Cibuntu - Cibitung \\ Tlp/Fax : ( 021 ) 8254640
}

\author{
DR.Gloria N,MT \\ Dosen STTD \\ J1. Raya Setu no.89 \\ Cibuntu - Cibitung \\ Tlp/Fax : ( 021 ) 8254640
}

Purwatiningsih,SH,MH

Dosen STTD

J1. Raya Setu no.89

Cibuntu - Cibitung

Tlp/Fax : ( 021 ) 8254640

\author{
Aryanti Fitrianingsih,MT \\ Dosen STTD \\ Jl. Raya Setu no.89 \\ Cibuntu - Cibitung \\ Tlp/Fax : ( 021 ) 8254640
}

\author{
Khusnul Khotimah,MT \\ Dosen STTD \\ Jl. Raya Setu no.89 \\ Cibuntu - Cibitung \\ Tlp/Fax : ( 021 ) 8254640
}

\author{
Sudirman Anggada,MT \\ Dosen STTD \\ Jl. Raya Setu no.89 \\ Cibuntu - Cibitung \\ Tlp/Fax : ( 021 ) 8254640
}

\begin{abstract}
From the World Health Organization (WHO) revealed that 48 percent of the deceased were productive (15-44 years old). The accidental casualties with high school level education (SLA) occupied the most numbers. Data from the POLRI Traffic Corps showed the percentage of victims with a high school education background reached 57 percent. The second highest number is the education background of Junior High School (SLTP), by 17 percent. Then followed by elementary education background (SD) as much as 12 percent. And then the background of Higher Education (PT) of 6 percent. young drivers are very potentially big cause of accidents on the highway. At the present time this young driver is in the $Z$ generation that has an age between 16-21 years
\end{abstract}

Keywords: accidental, young drivers, the Z generation

\begin{abstract}
ABSTRAKSI
Dari World Health Organization (WHO) mengungkapkan 48 persen korban yang meninggal merupakan usia produktif (15-44 tahun).Korban kecelakaan lalu-lintas dengan tingkat pendidikan sekolah lanjutan atas (SLA) menempati angka paling banyak.Data dari Korps LaluLintas POLRI menunjukan persentasi korban dengan latar belakang pendidikan SLTA mencapai 57 persen.Angka terbanyak kedua adalah latar belakang pendidikan Sekolah Lanjutan Tingkat Pertama (SLTP), sebesar 17 persen.Kemudian disusul latar belakang pendidikan Sekolah Dasar (SD) sebanyak 12 persen.Dan kemudian latar belakang Perguruan Tinggi (PT) sebesar 6 persen. pengemudi muda sangat berpotensi besar penyebab kecelakaan di jalan raya. Pada saat sekarang ini pengemudi muda tersebut berada pada generasi $\mathrm{Z}$ yang memiliki usia antara 16-21 tahun
\end{abstract}

Kata kunci : Kecelakaan, anak muda, generasi z 


\section{PENDAHULUAN}

Angka kematian akibat kecelakaan di jalan raya tiap tahun mengalami peningkatan. Jumlah korban kecelakaan pada usia produktif cenderung meningkat, walaupun pada tahun 2010 terjadi penurunan. Namun dari tahun 2012 sampai dengan tahun 2013 terjadi pelonjakan yang sangat tajam, yaitu sebesar $181 \%$. Angka tersebut cukup besar melebihi tahun-tahun sebelumnya.Tidak begitu jauh berbeda, pada tahun 2015-2016 korban kecelakaan pada usia produktif masih berada pada urutan tertinggi seperti ditampilkan pada diagram berikut:

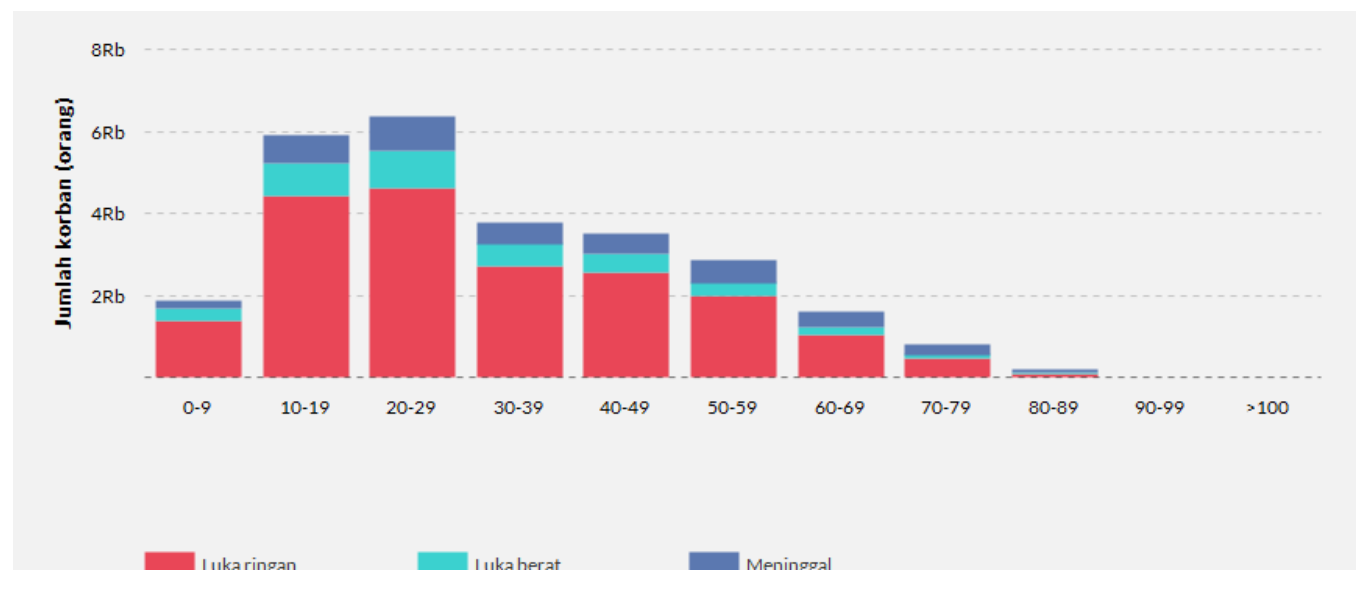

Gambar 1. Jumlah Korban Kecelakaan Lalu Lintas Darat Berdasarkan Jenis Luka dan Kelompok Umur Tahun 2015-2016 (Polri)

Data dari Analisa dan Evaluasi (Anev) Laka lantas 2015-2016 menyebutkan, angka kecelakaan pada 2016 mencapai 125 kejadian, dengan korban meninggal mencapai 30 jiwa, dan kerugian material mencapai Rp387.150.000. Angka tersebut mengalami kenaikan sekitar 148 persen atau 74 kejadian.Dibanding angka kecelakaan di 2015 yang mencapai 50 kejadian, dengan korban meninggal mencapai 20 jiwa, dan kerugian material mencapai Rp182.150.000.

Dari uraian diatas dapat disimpulkan pengemudi muda sangat berpotensi besar penyebab kecelakaan di jalan raya. Pada saat sekarang ini pengemudi muda tersebut berada pada generasi $\mathrm{Z}$ yang memiliki usia antara 16-21 tahun. Berdasarkan hal-hal tersebut maka peneliti melakukan penelitian yang berjudul "Analisis Pembeda Karakteristik Perilaku Mengemudi Pada Generasi Z di Sekolah Tinggi Transportasi Darat."

\section{A. PERUMUSAN MASALAH}

Dari latar belakang diatas, maka perumusan masalah dalam penelitian ini dapat diuraikan sebagai berikut :

1. Bagaimana karakteristik pengemudi generasi $\mathrm{Z}$ penyebab masalah utama kecelakaan? 
2. Apa saja faktor pembeda pada generasi $\mathrm{Z}$ yang paling dominan menyebabkan kecelakaan?

3. Apa saja upaya-upaya yang dapat meningkatkan keselamatan berlalu lintas?

\section{B. TUJUAN}

Tujuan penelitian ini adalah sebagai berikut:

1. Mengidentifikasi karakteristik mengemudi kalangan Generasi $Z$

2. Menganalisa faktor pembeda penerasi Zpaling dominan yang menyebabkan kecelakaan

3. Merekomendasikan upaya-upaya peningkatan keselamatan berlalu lintas pada kalangan Generasi Z

1. Profil Generasi Z (Lahir Tahun 1995-2010)

Genarasi $\mathrm{Z}$ disebut juga iGeneration, generasi net atau generasi internet.Mereka memiliki kesamaan dengan generasi Y namun, mereka mampu mengaplikasikan semua kegiatan dalam satu waktu.Contohnya, bermain twitter dengan ponsel, browsing dengan PC, dan mendengarkan musik menggunakan headset.Apapun yang dilakukan kebanyakan berhubungan dengan dunia maya.

Sejak kecil mereka sudah mengenal teknologi dan akrab dengan gadget canggih yang secara tidak langsung berpengaruh terhadap kepribadian mereka.Kemudahan tersebut membuat mereka sangat intens berkomunikasi dan berinteraksi dengan semua kalangan, khususnya dengan teman sebaya melalui berbagai situs jejaring, seperti: FaceBook, Twitter, atau Instagram, Whatsapp dan berbagai aplikasi lainnya.

Melalui berbagai media tersebut, mereka juga terbiasa bisa mengekspresikan apa yang dirasakan dan dipikirkannya secara lebih spontan.Selain itu, akses informasi global yang tanpa batas tersebut juga membuat mereka lebih luwes dalam berinteraksi dengan siapapun di seluruh penjuru dunia, sehingga cenderung lebih toleran dengan perbedaan kultur dan sangat peduli dengan isuisu sosial yang digulirkan sosial media. Namun, tsunami informasi tersebut juga membuat mereka rentan terkena hal-hal negatif dari mengonsumsi informasi yang salah.

Karakteristik generasi Z ini dapat diuraikan sebagai berikut:

a. CakapTeknologi

Karakter utama dari generasi $\mathrm{Z}$ adalah melek internet dan begitu mahir dengan segala hal berbau digital.Generasi $\mathrm{Z}$ merupakan anak muda yang bergantung pada teknologi informasi dan komunikasi dalam setiap aktivitasnya.Teknologi informasi dan komunikasi digunakan untuk kebutuhan pendidikan maupun bersosialisasi secara pribadi atau kelompok dengan akses cepat.Generasi $\mathrm{Z}$ sangat menyukai komunikasi melalui dunia maya atau media sosial dimana lebih bebas berekspresi dan berfikir secara spontan. 
b. Bersosialisasi Lewat Media Sosial

Generasi $\mathrm{Z}$ sangat intens berkomunikasi dengan semua kalangan -terutama teman-temannya- melalui internet seperti Facebook, instagram, twitter dan sebagainya.

Melalui media sosial, mereka bebas mengekspresikan perasaan dan pikirannya dengan spontan.Generasi $\mathrm{Z}$ cenderung toleran dengan perbedaan budaya dan sangat aktif dalam isu berbau lingkungan.

Generasi ini hampir setiap hari dipastikan mencurahkan apa saja isi hati ke dalam media sosial. Bahkan dalam tataran yang lebih ekstrem, mereka bahkan berani memprotes dan mengungkapkan kekesalan mereka di media sosial.

c. Multitasking

Generasi $\mathrm{Z}$ terbiasa dengan aktivitas yang dilakukan dalam waktu bersamaan, seperti membaca, mendengarkan musik, berbicara dan menonton.Hal ini terjadi karena karakter generasi $\mathrm{Z}$ yang menginginkan efisiensi tanpa bertele-tele.

d. Egosentris dan Individualis

Generasi ini bersikap egosentris dan individualis. Mereka menginginkan hal-hal yang instan, kurang menghargai proses, cepat marah dan tidak sabaran.

Mungkin IQ mereka tinggi dan berkembang baik, namun, EQ mereka menjadi jongkok.Mereka tidak lagi peduli dengan keadaan di sekitar mereka.

Mereka masih terlalu asyik dengan gadget dan fokus pada permainan yang mereka lakukan.Seakan mereka hidup dalam dunia mereka sendiri.

\section{A. METODE PENGUMPULAN DATA}

Pengumpulan data dilakukan dengan beberapa metode yaitu:

1. Studi Literatur

Pengumpulan referensi dan literatur untuk dipahami mengenai perilaku berkeselamatan pengemudi.

2. Observasi Perilaku Mengemudi

Mengumpulkan data primer terkait perilaku pengemudi.

3. Wawancara

Perlengkapan Pengumpulan Data meliputi:

1. Kuesioner kebiasaan Mengemudi

2. Formulir pengamatan Cara Mengemudi

3. Stimuli eksperimental berupa 5 skenario lalu lintas jalan simulasi yang diterapkan pada simulator mengemudi.

Skenario yang diterapkan sebagai stimuli meliputi:

1. Bermanuver tanpa ada lalu lintas lainnya.

2. Manuver yang diperlukan pengemudi untuk belok kanan di persimpangan melalui arus lalu lintas, dengan traffic mendekati dari kanan,

3. Manuver belok kanan dengan lalu litas bergabung dari arah kiri, 
4. Manuver belok kanan saat lalu lintas lain mendekati dari arah kanan dan kiri

5. Manuver lurus saat melintas menyeberang persimpangan dengan semua lalu lintas dari semua pendekat.

Peralatan Pengumpulan Data adalah Simulator mengemudi.Simulator mengemudi terdiri rangkaian penilaian pengemudi terhadap berbagai situasi lingkungan jalan yang disimulasikan dan sistem akuisisi data hasil mengemudi.Bagian pengemudi pada simulator terdiri dari kursi mobil, kemudi, dashboard, dan pedal.

Bagian stimuli berupa perangkat dengan 3 layar monitor berupa tampak situasi depan dan spion situasi belakang, samping kanan kiri, dan spion samping. Simulator yang akan digunakan adalah simulator mengemudi bus pada Laboratorium Lalu Lintas dan Angkutan Jalan Sekolah Tinggi Transportasi Jalan, sebagaimana ditunjukkan pada Gambar 6.
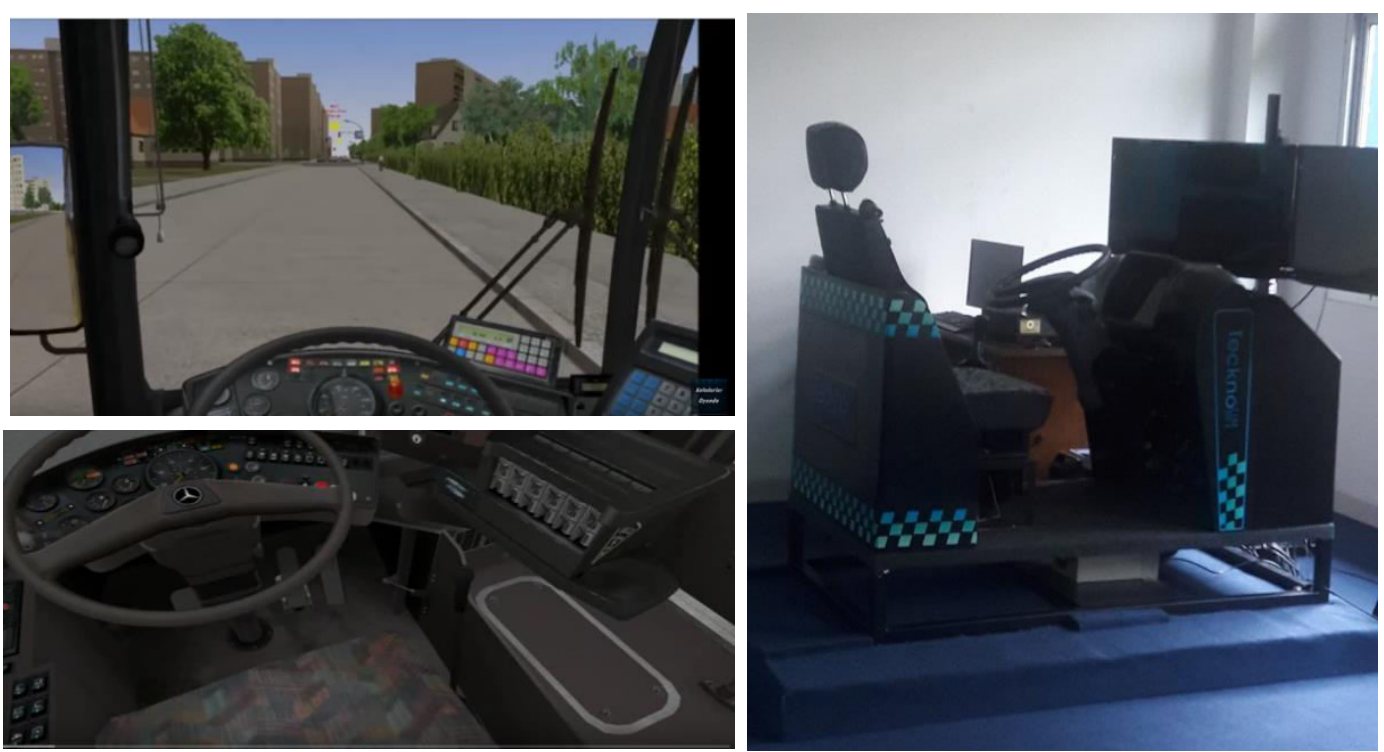

Gambar 2. Simulator Mengemudi Bus TekSim

\section{Metode Analisis}

a. Metode Analisis Cross Tab

Tabulasi silang merupakan metode analisis kategori data yang menggunakan data nominal, ordinal, interval, serta kombinasi diantaraya.Prosedur tabulasi silang digunakan untuk menghitung banyaknya kasus yang mempunyai kombinasi nilai-nilai yang berbeda dari dua variabel. (Indarto, I., \& Irwinsyah, R., 1997), Tabulasi silang merupakan metode untuk mentabulasikan beberapa variabel yang berbeda ke dalam suatu matriks.Hasil tabulasi silang disajikan ke dalam suatu tabel dengan variabel-variabel yang tersusun 
sebagai kolom dan baris. Kegunaan Analisis Tabulasi Silang menurut Jubaedah, Siti, et al. (2014) adalah :

1) Alat bantu untuk melihat apakah terdapat suatu hubungan atau asosiasi (hubungan kuat/ lemah) dari dua variabel atau lebih;

2) Mempermudah analisis dalam data dua variabel atau lebih;

3) Mempermudah pengerjaan dalam mencari hubungan antar data (ada atau tidaknya hubungan di dalam data).

Metode analisis cross tab digunakan untuk membandingkan dan melihat adanya suatu pola hubungan antara dua variabel yang berbeda. Dalam penelitian ini, metode analisis cross tab dilakukan untuk mengetahui hubungan antara variable bebas dan variable terikat yang diduga penyebab dominan kecelakaan pada generasi $\mathrm{Z}$.

b. Metode Analisis Chi Square

Chi-Square disebut juga dengan Kai Kuadrat. Chi Square adalah salah satu jenis uji komparatif non parametris yang dilakukan pada dua variabel, di mana skala data kedua variabel adalah nominal. (Apabila dari 2 variabel, ada 1 variabel dengan skala nominal maka dilakukan uji chi square dengan merujuk bahwa harus digunakan uji pada derajat yang terendah).

Uji chi-square merupakan uji non parametris yang paling banyak digunakan. Namun perlu diketahui syarat-syarat uji ini adalah: frekuensi responden atau sampel yang digunakan besar, sebab ada beberapa syarat di mana chi square dapat digunakan yaitu:

1) Tidak ada cell dengan nilai frekuensi kenyataan atau disebut juga Actual Count (F0) sebesar 0 (Nol).

2) Apabila bentuk tabel kontingensi $2 \times 2$, maka tidak boleh ada 1 cell saja yang memiliki frekuensi harapan atau disebut juga expected count ("Fh") kurang dari 5.

3) Apabila bentuk tabel lebih dari $2 \times 2$, misak $2 \times 3$, maka jumlah cell dengan frekuensi harapan yang kurang dari 5 tidak boleh lebih dari $20 \%$.

Uji Chi Square berguna untuk menguji hubungan ataupengaruh dua buah variabel nominal dan mengukurkuatnya hubungan antara variabel yang satu denganvariabel nominal lainnya ( $\mathrm{C}=$ Coefisien of contingency). Dalam penelitian ini variable bebas dan variable terikat yang diduga penyebab kecelakaan pada generasi $\mathrm{Z}$ yang akan diujikan. 


\section{A. ANALISIS KARAKTERISTIK KLINIS PENGEMUDI GENERASI Z 1. Waktu Reaksi Pengemudi Generasi "Z" (Reaction Time Of " $Z$ " Generation Driver)}

Waktu yang diperlukan antara melihat suatu kejadian, mengolah informasi tersebut diotak untuk kemudian mengambil reaksi disebut sebagai waktu reaksi, atau didalam berbagai referensi disebut sebagai PIEV sebagai singkatan dari Perception, Intelection, Emotion dan Volition.

Perception, merupakan saat pandangan mata yang menangkap adanya suatu keadaan/ancaman dihadapan pengemudi.

Intelection, informasi yang diperoleh mata selanjutnya dikirim ke otak oleh syaraf mata, informasi diolah oleh otak dengan menggunakan kecerdasan otak dengan menggunakan ingatan masa lalu ataupun analisis keadaan.

Emotion, pengambilan keputusan diotak, mengenai langkah yang akan dilakukan untuk menghadapi keadaan/ancaman dengan berbagai pertimbangan-pertimbangan yang sering-sering dipengaruhi oleh emosional pengemudi.

Volition, merupakan instruksi yang telah diolah untuk diteruskan melalui syaraf kepada tindakan yang akan diambil oleh tangan, dan kaki pengemudi.

Waktu PIEV seorang pengemudi rata-rata 2,5 detik tetapi dapat lebih cepat pada orang-orang tertentu seperti pembalap yang harus mengambil tindakan/langkah dengan sangat cepat dan lebih lama pada orang-orang yang lebih tua, minum obat, kelelahan, gangguan phisik pada penderita cacat, cuaca.

Dari hasil uji simulator waktu reaksi yang dilakukan pada generasi "Z" didapatkan bahwa rata-rata generasi " $Z$ " memiliki nilai kurang dari standar yaitu sebesar 59,33 dari standar nilai yang dilakukan adalah 60 . Nilai tersebut dikonversikan ke dalam waktu response.Dengan waktu response untuk uji waktu reaksi pada generasi " $Z$ " sebesar 1,91 detik. Hanya saja dari sampel responden generasi " $Z$ " paling banyak memiliki waktu reaksi 61 atau diatas standar dengan waktu response sebesar 1,99. Hal ini dapat disimpulkan untuk generasi " $Z$ " memiliki waktu reaksi yang sangat cepat. Berikut akan ditampilkan hasil survey dari sampel uji waktu reaksi dari simulator pada generasi "Z".

Pada bagian mengemudi defensive, mengerti adalah tindakan antisipatif. Ketika indera mata melihat sesuatu, maka pengemudi paham objek tersebut.

Dari hasil uji simulator antisipasi pengemudi yang dilakukan Pemusatan Data Waktu Reaksi Pengemudi Generasi " $Z$ " 
TABEL I

\begin{tabular}{|c|c|c|c|}
\hline Pemusatan Data & Score Standart & Score & $\begin{array}{c}\text { Response } \\
\text { (Detik) }\end{array}$ \\
\hline Mean & 60 & 59.333 & 1.906103333 \\
\hline Median & 60 & 61 & 1.925 \\
\hline Modus & 60 & 62 & 1.99 \\
\hline
\end{tabular}

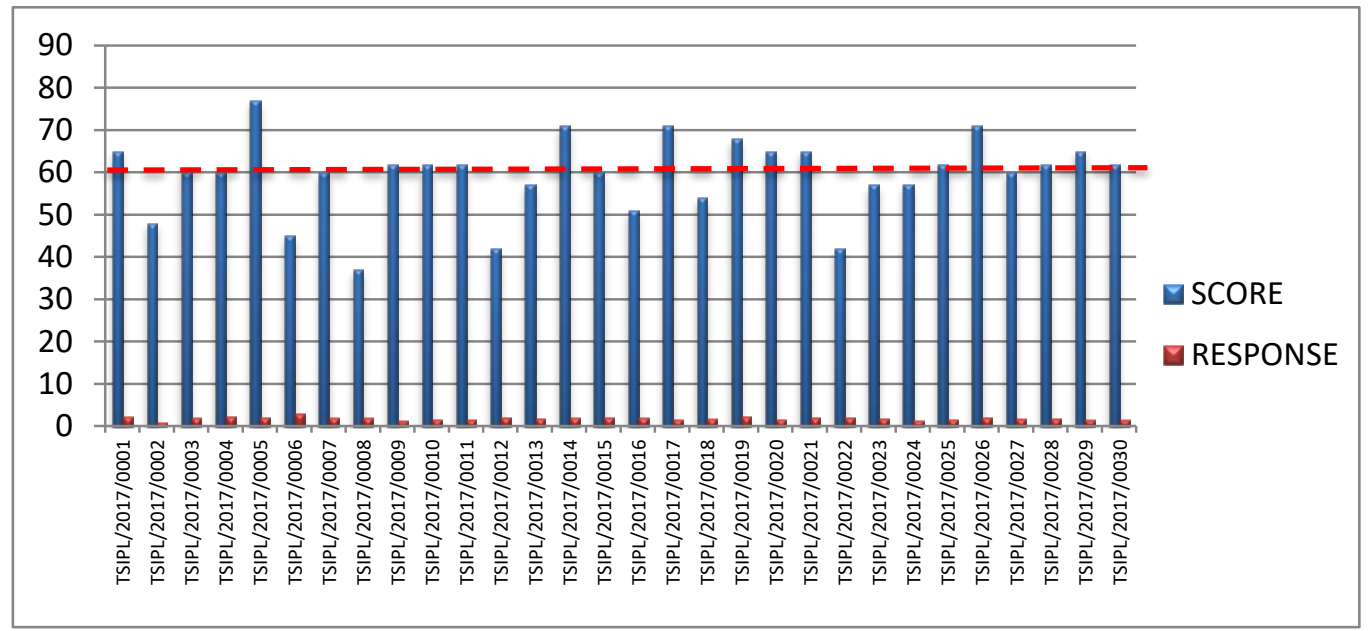

Gambar 3. Diagram Waktu Reaksi Pengemudi Generasi "Z"

\section{Ketangkasan Mengemudi Generasi " $Z$ " (Driving Aptitude of " $Z$ " Generation Driver)}

Dari hasil uji simulator ketangkasan mengemudi yang dilakukan pada generasi " $Z$ " didapatkan bahwa rata-rata generasi " $Z$ " memiliki nilai kurang jauh dari standar yaitu sebesar 35,73 dari standar nilai yang dilakukan adalah 60. Dengan waktu response untuk uji ketangkasan mengemudi pada generasi "Z" sebesar 7,71 detik. Begitu pula dari sampel responden generasi " $Z$ " paling banyak memiliki nilai ketangkasan mengemudi sebesar 2 atau dibawah standar dengan waktu response yang sangat cepat sebesar 0,6. Hal ini dapat disimpulkan untuk generasi " $Z$ " memiliki ketangkasan mengemudi yang kurang baik. Berikut akanditampilkan hasil survey dari sampel uji ketangkasan mengemudi dari simulator pada generasi " $Z$ ". 
Tabel 1. Pemusatan Data Ketangkasan Mengemudi Generasi " $Z$ "

\begin{tabular}{|c|c|c|c|}
\hline Pemusatan Data & Score Standart & Score & Response \\
\hline Mean & 60 & 35.7333 & 7.713517241 \\
\hline Median & 60 & 42 & 3.73 \\
\hline Modus & 60 & 2 & 0.6 \\
\hline
\end{tabular}

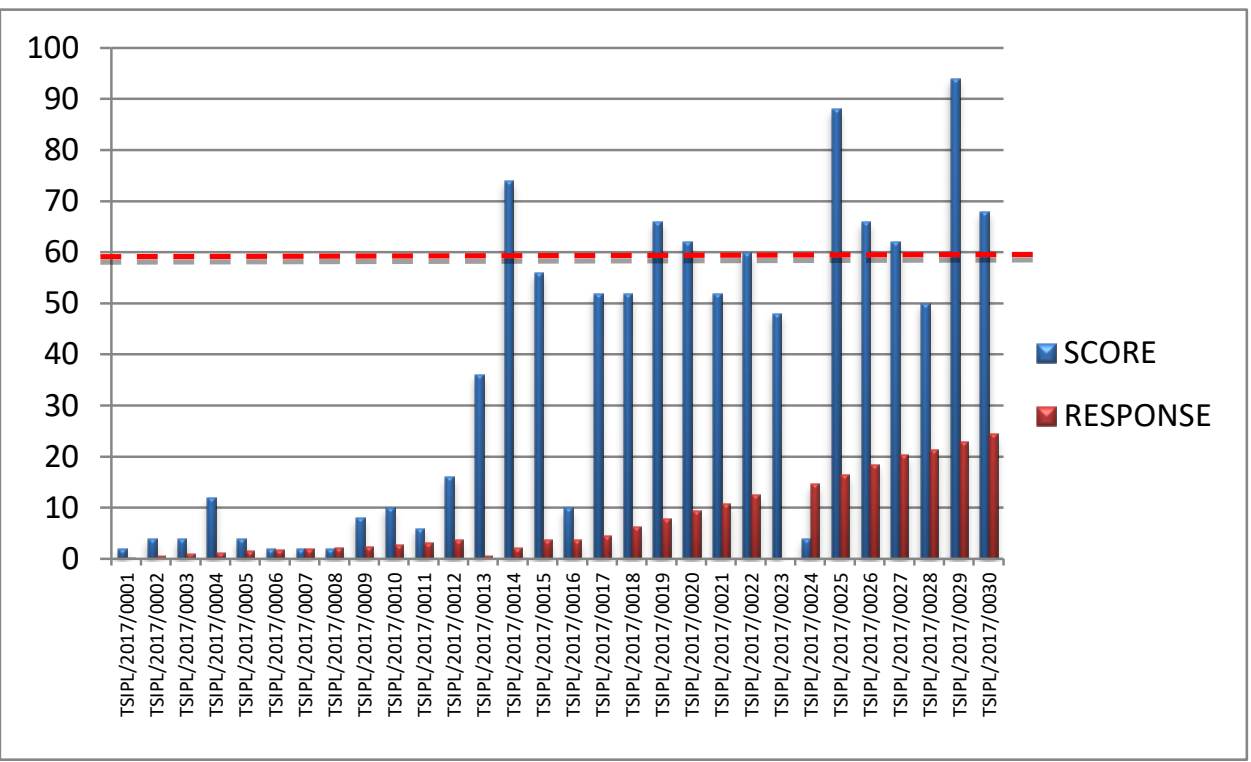

Gambar 4. Diagram Ketangkasan Mengemudi Generasi "Z"

\section{Antisipasi Pengemudi Generasi " $Z$ " (Anticipation of "Z" Generation} Driver)

pada generasi " $Z$ " didapatkan bahwa rata-rata generasi " $Z$ " memiliki nilai kurang jauh dari standar yaitu sebesar 31,03dari standar nilai yang dilakukan adalah 60. Begitu pula dari sampel responden generasi " $Z$ " paling banyak memiliki nilai antisipasi mengemudi 20 atau dibawah standar. Hal ini dapat disimpulkan untuk generasi "Z" memiliki antisipasi mengemudi yang kurang baik.Indikasi yang menyebabkan tidak antisipatif salah satunya adalah mengerem mendadak, danmelakukan manuver mendadak.Lalu, kaget atas kejadian yang ada dimukanya dan pergerakan kendaraan walaupun pelan selalu tidak halus.

Berikut akan ditampilkan hasil survey dari sampel uji antisipasi mengemudi dari simulator pada generasi "Z". 
Tabel 2. Pemusatan Data Antisipasi Pengemudi Generasi " $Z$ "

\begin{tabular}{|c|c|c|}
\hline Pemusatan Data & Score Standart & Score \\
\hline Mean & 60 & 31.0333 \\
\hline Median & 60 & 25 \\
\hline Modus & 60 & 20 \\
\hline
\end{tabular}

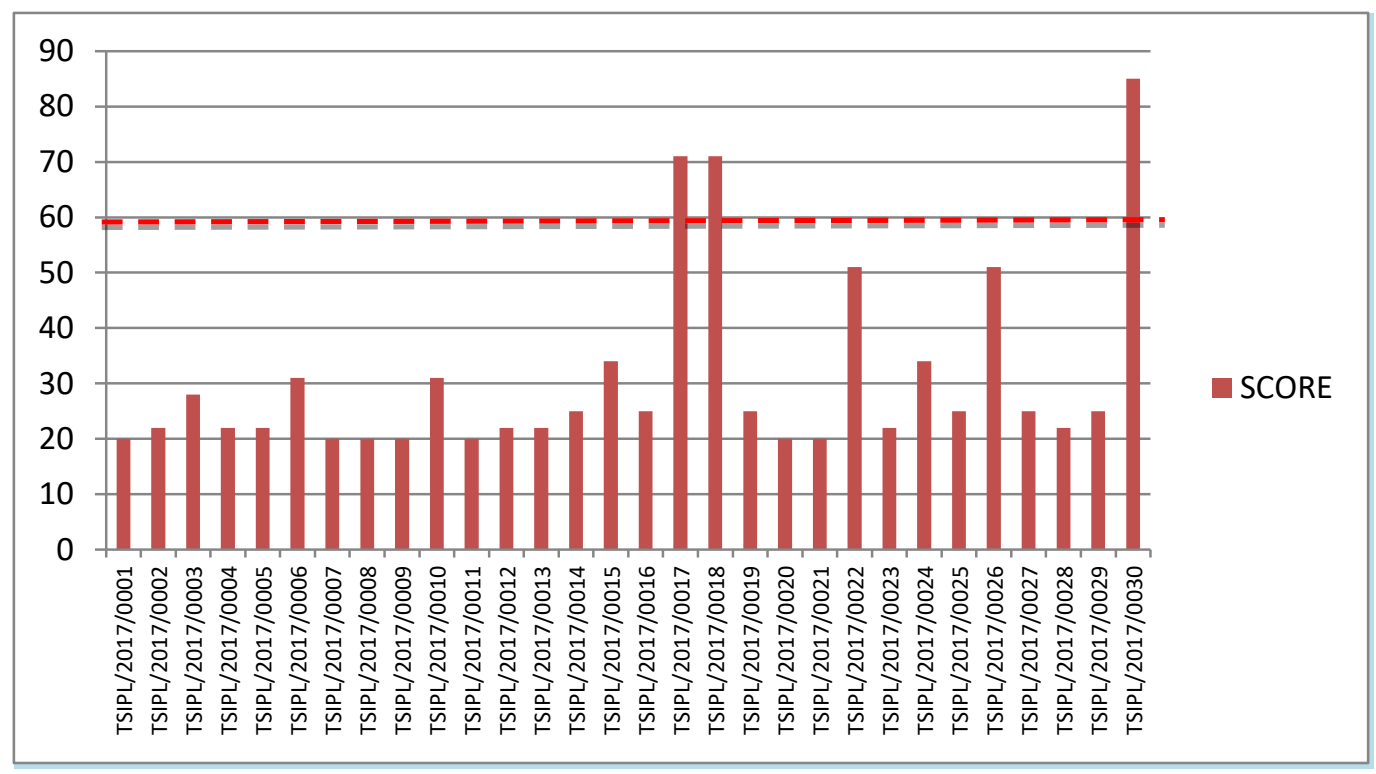

Gambar 5. Diagram Antisipasi Pengemudi Generasi "Z"

\section{Pengambilan Keputusan generasi " $Z$ " (Decision making of " $Z$ " Generation Driver)}

Faktor risiko, sangat dekat dengan pengambilan keputusan. Sepanjang waktu (proses) mengemudi, pengambilan keputusan itu, berlangsung terus menerus. Ini berkaitan dengan aktivitas mengontrol kemudi, kopling, rem, gas, dan klakson serta instrument lain.

Dari hasil uji simulator pengambilan keputusan yang dilakukan pada generasi " $Z$ " didapatkan bahwa rata-rata generasi " $Z$ " memiliki nilai sesuai dengan standar yaitu sebesar 62,67 dari standar nilai yang dilakukan adalah 60. Begitu pula dari sampel responden generasi " $Z$ " paling banyak memiliki nilai pengambilan keputusan dalam mengemudi sebesar 60 atau sesuai standar.Hal ini dapat disimpulkan untuk generasi "Z" memiliki pengambilan keputusan yang cukup baik. Reaksi yang sangat cepat dan gesit membuat generasi " $Z$ " sangat baik dalam mengontrol instrument kendaraan seperti control kemudi, rem, kopling, gas, klakson, dan instrument lainya.

Berikut akan ditampilkan hasil survey dari sampel uji pengambilan keputusan mengemudi dari simulator pada generasi " $Z$ ". 
Tabel 3. Pemusatan Data Pengambilan Keputusan Generasi "Z"

\begin{tabular}{|c|c|}
\hline Pemusatan Data & Score \\
\hline Mean & 62.66666667 \\
\hline Median & 60 \\
\hline Modus & 60 \\
\hline
\end{tabular}

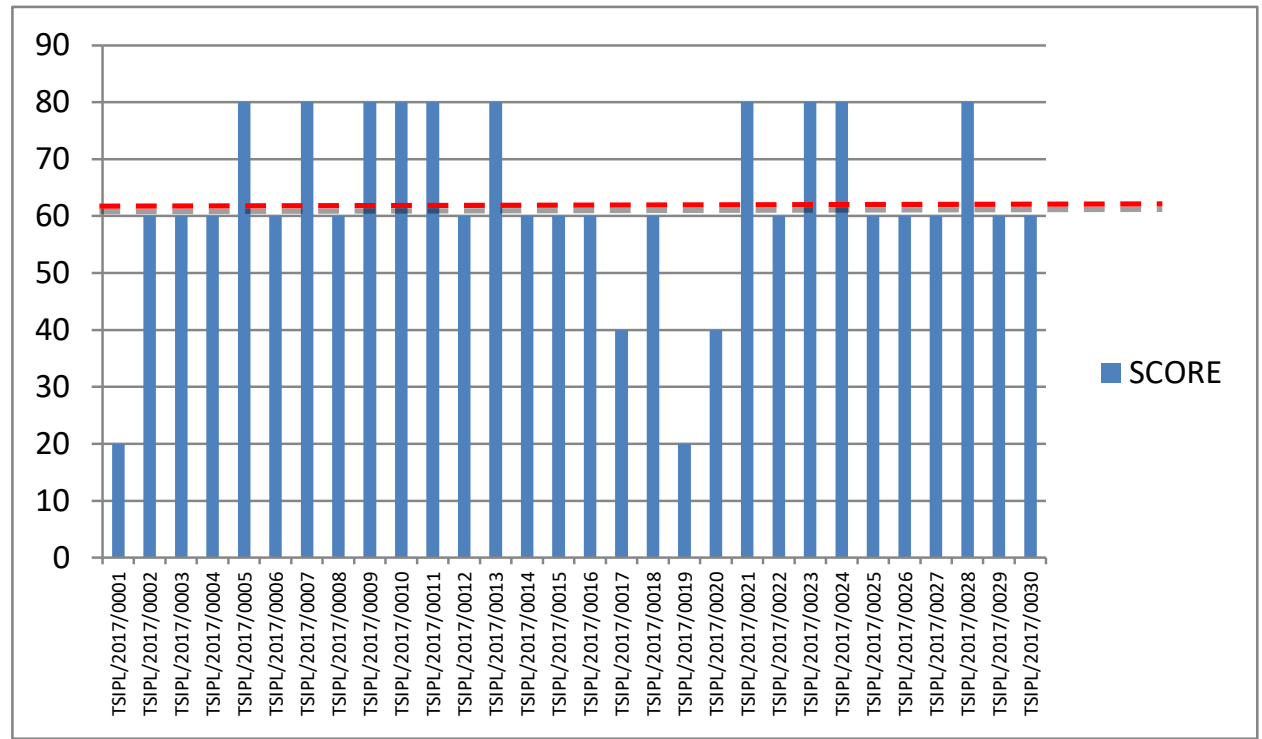

Gambar 6. Diagram Pengambilan Keputusan Generasi "Z"

\section{PENUTUP}

\section{A. KESIMPULAN}

1. Karakteristik Klinis Mengemudi Kalangan Generasi Zpaling dominan penyebab kecelakaan secara deskriptif dari hasil uji simulator adalah sebagai berikut:

a. Waktu Reaksi

Generasi "Z" memiliki waktu reaksi yang sangat cepat.Waktu PIEV seorang pengemudi rata-rata 2,5 detik, dari sampel responden generasi " $Z$ " paling banyak memiliki waktu reaksi/waktu response sebesar 1,99 detik.

b. Ketangkasan Mengemudi

Generasi " $Z$ " memiliki ketangkasan yang sangat buruk atau sekitar 50\% dari standar.

c. Antisipasi Mengemudi

Generasi " $Z$ " memiliki antisipasi mengemudi yang sangat buruk atau sekitar 50\% dari standar.Indikasi yang menyebabkan tidak antisipatif salah satunya adalah mengerem mendadak, danmelakukan manuver mendadak.Lalu, kaget atas kejadian yang ada dimukanya dan pergerakan kendaraan walaupun pelan selalu tidak halus. 


\section{d. Pengambilan Keputusan}

Generasi "Z" memiliki pengambilan keputusan dalam mengemudi yang baik atau sesuai standar.Reaksi yang sangat cepat dan gesit membuat generasi " $Z$ " sangat baik dalam mengontrol instrument kendaraan seperti kontrol kemudi, rem, kopling, gas, klakson, dan instrument lainya.

e. Buta Warna

Generasi "Z" dalam uji buta warna rata-rata normal / tidak mengalami buta warna.

f. Penglihatan

Generasi "Z" dalam uji penglihatan rata-rata optimal / tidak mengalami gangguan penglihatan.

2. Karakteristik Stimuli Kalangan Generasi Zpaling dominan penyebab kecelakaan secara deskriptif dari hasil uji simulator adalah sebagai berikut:
a. Eco / Smart Drive
Generasi " $Z$ " belum bisa memperbaiki cara mengemudi serta belum bisa mencegah pemborosan konsumsi BBM.
b. Defensive Drive
Jika dilihat dari segi defensive (aman) generasi " $Z$ " cenderung tabrakan dengan kendaraan lain.

3. Upaya-Upaya Peningkatan Keselamatan Berlalu Lintas Pada Kalangan Generasi Z

a. Dari Segi Klinis

- Waktu Reaksi (desain perhitungan waktu hijau/merah pada alat pengendali isyarat lalu lintas (apill), standar penempatan rambu dan lain sebagainya)

- Pengambilan Keputusan (Penyebaran pamphlet, spanduk keselamatan)

- Penglihatan (Evaluasi penempatan rambu sesuai petunjuk teknis penempatan perlengkapan jalan)

b. Dari Segi Stimuli Generasi "Z"

- Kawasan Tertib Lalu Lintas

c. Dari Segi Klinis (Ketangkasan) dan Stimuli (Wawasan) Generasi "Z”

- Sosialisasi Keselamatan di sekolah-sekolah

d. Dari Segi Kepemilikan Sim

- Revitalisasi pelayanan surat ijin mengemudi

e. Eco Drive

1) Hindari memanaskan mesin terlalu lama sebelum berkendara

2) Pertahankan kecepatan kendaraan secara konstan

3) Hindari kecepatan yang terlalu tinggi

4) Sesuaikan gigi percepatan dengan kecepatan

5) menghindari pengereman dan akselerasi yang tidak perlu

6) Hindari muatan yang berlebihan

7) Bijak menggunakan AC 
f. Defensive Drive

1) Waspada

2) Sikap dan Mental tidak egois dan mau menang sendiri

3) Antisipasi

\section{B. SARAN}

Pada penelitian ini, masih dalam tahap menemukan karakteristik-karakteristik yang menjadi pembeda penyebab kecelakaan yang paling dominan saja pada generasi "Z".Dibutuhkan penelitian lebih lanjut terkait meminimalisir kecelakaan pada tiap-tiap faktor yang dominan

\section{DAFTAR PUSTAKA}

,2008, Human Factors For Transport Safety Investigators, Kementrian Perhubungan Darat, Jakarta

,2009,Undang-undang Nomor 22 Tahun 2009 Tentang Lalu Lintas dan Angkutan Jalan, Direktorat Jenderal Perhubungan Darat, Jakarta

Barnard, Yvonne, etc, The Safety Of Intelligent Driver Support Systems, Ashgate Publishing Company, USA

Elvik, Rune, etc, 2009, The Handbook Of Road Safety Measures Second Edition, Emerald Group Publishing Company

J. Supranto , 2000,Teori dan Aplikasi Statistik, Erlangga, Jakarta

Notoadmodjo, 2007, Teori Keperilakuan Dalam Pengambilan Keputusan, Erlangga, Jakarta

Suartana, I Wayan, 2010, Konsep Teori Keperilakuan Transportasi, Andi, Yogyakarta

Sugiyono, 2011, Metode Penelitian Kuantitatif Kualitatif Dan $R \&$ D, Alfabeta, Bandung

OECD, 2003, Road Safety Impact Of New Technologies, Securite Routiere, OECD Publishing Company

OECD, 2006, Young Drivers The Road To Safety, European Conference Of Ministers Of Transport 
